\title{
Multicultural Competence and Interactional Justice on Performance of Government Apparatus: Evidence from Lampung Province
}

\author{
Suyanto ${ }^{*}$, Nedi Hendri ${ }^{1}$, Karnila Ali ${ }^{1}$ \\ ${ }^{1}$ Faculty of Economics, Muhammadiyah University of Metro, Metro, Indonesia \\ ${ }^{*}$ Corresponding author. Email: yanto.metro@ gmail.com
}

\begin{abstract}
The study of management control in government organizations has missed important issues to examine the role of multicultural competence in fostering working relationships and achieving better performance. This study aims at test empirically about how the influence of multicultural competence and interactional justice to apparatus performance. The study was conducted at the government apparatus in Lampung ProvinceIndonesia. The study applied a survey method and samples determination was based on a purposive sampling technique. The study collected 143 respondents. The data was analysed by a Structural Equation Model (SEM) operated under AMOS application program. This study provides a better understanding, namely the influence of multicultural competence on the performance of government apparatus tend to be indirect influence through its ability to create interactional justice. This result may be used to develop the management control theory based multicultural competence in which analysed in integrated model.
\end{abstract}

Keywords: multicultural competence, interactional justice, government apparatus

\section{INTRODUCTION}

Governmental organizations in Indonesia have undergone many changes in institutional, organizational and managerial in order to meet the increasing need for services, efficiency and effectiveness. The change of the government organization demands the optimization of the implementation of management control so that the objectives and performance improvement of the apparatus can be achieved. This is because in essence the government organization is a public organization that must be run for the sake of public.

Performance increase is ideal if it is accompanied by attention to factors that affect the psychological condition of the apparatus. Reference [1] explains that performance improvement does not depend on intellectual and managerial capacity, but on the behavior and competence of various cultures (multicultural). Competence development process should cover all efforts to build knowledge and skills and good attitude in accordance with the cultural conditions of society equally. Culture can be software of mind that distinguishes it from other social groups.

Culture is one of the topics that attrats the researchers' interest from various disciplines. This is because culture has an ever-evolving definition, marked by the phenomenon of a never-ending cultural definition. Matsumoto [2] describes culture as a system of values, attitudes, beliefs and behaviors held by groups of people, while Ralph Linton [3] emphasizes culture as an aspect of habit that is inherited in certain members of society. In addition, culture as one of the external factors that influence one's behavior [4]. Some research, found that employee behavior is a function of interaction between personal characteristics and the environment. The environment contains a social culture that affects the work so that it can be called work culture. Reference [5] states that culture influences one's behavior or attitudes through the values it carries through its surroundings. With this understanding, different cultural perceptions will dictate different attitudes and behaviors and affect personal responsibility, attitudes to authority and law, use of time, respect for rules, and fair treatment. Such issues have such an important role in fostering employment and achieving better performance.

Multicultural competence is the ability to understand the identity and values of different cultures that are embraced by itself and how they affect their perceptions of others from different cultures [6]. Multicultural competence can be summarized into three dimensions: knowledge, skills, and motivation. Knowledge in this competence includes cultural parameters and how they influence. Skills include curiosity and the ability to get new information, analyze it, communicate well with managing responses to the results of analysis, and flexibly adapt. Motivation includes understanding of cultural differences and respecting the underlying desire to learn, improve and improve in order to manage them better. Another opinion, describes that the area of multicultural competence includes several aspects: valuing diversity, being culturally self-aware, understanding the dynamics of cultural interaction, and institutionalizing cultural knowledge and adapting to diversity [7].

Research on culture in government organizations has long received the attention of some researchers. The discussed research focus for example: impact of work culture on motivation and performance [8]; organizational cultural competence: a review of assessment protocols [9]; culture, government and development in South Korea [10]; influence culturized bureaucracy to apparatus performance 
at Regency Region secretariat Bolaang Mongondow North [11]; and multicultural competence of counselors on Dayak culture in Central Kalimantan [12]. Nevertheless, some of these studies have not yet conducted an integrated analysis that links the cultural, trust and interactional justice factors to the performance of government apparatus.

This research was carried out in Government of Lampung Province - Indonesia, because it was one of immigrantion area. Most of the people come from some parts of island of Java, such as: Semarang, Yogyakarta, Banyumas, Tegal, East Java, and the island of Bali. As one of immigrant destination areas, each community in Lampung Province has different regional languages, customs, customs and cultures. The empirical consequence of societal conditions that have multicultural dynamics is the need for multicultural competence to understand and address behavior in different cultural contexts. This research is expected to be useful in developing management control theory as well as providing practical contribution to human resource management in government organizations. The research focus is the role of multicultural competence and interactional justice in improving the performance of government apparatus. Reference [13] define performance as a result of achievement or degree of accomplishment. This means that the performance of the apparatus is seen from the level of achieving a predetermined work objective or goal.

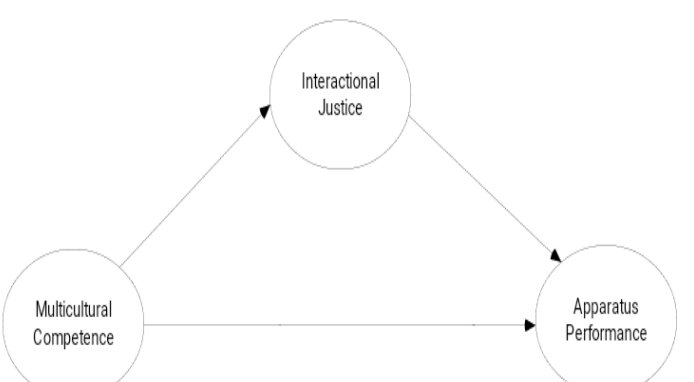

Figure 1 The role of multicultural competence and interactional justice in apparatus performance.

Figure 1 is the conceptual model underlying this research. The figure shows a model of whether and how the multicultural competence of the government apparatus can affect employee's performance.

First, multicultural competence has a direct effect on the performance of employee. Diversity breeds tolerance when members within an organization can accept each other and appreciate differences or diversity. The diversity that exists in this organization can be a source of harmony, and even an organization that has a different cultural background will have different ideas and ideas, so that creativity will arise in many ways. Hladik [14] suggests the need for cross-ethnic awareness and cultural differences from various members of the organization to improve employee performance. The multicultural existing in an organization is a positive potential that can be optimized through interaction between individuals to organizational culture [15]. In addition, that well-allocated multicultural competence will result in new innovations and can be used to add value to the company [16], [17]. Based on this description, it is obtained the hypothesis that is $\mathrm{H} 1$ : Multicultural competence directly affects the apparatus' performance.

Second, multicultural competence has an indirect effect on the performance of apparatus through interactional justice. In addition to multicultural competence, the factor to consider in improving performance is the existence of justice in the work environment. Reference [18] explain that justice is a determinant key of positive employee behavior. The results of a study show that current employees are more aware of justice and equality in the workplace [19]. Under these conditions, employees expect that local government leaders and organizations are responsible for creating a fair working environment. Reference [20] gives the meaning of justice as a fairness. This means that any social institution or social system that exists should be able to treat each individual fairly. Based on the theory of group values, shows that a person is essentially a social being who needs to affiliate or mingle with others and assign value to group membership. So justice by treating people through groups is very important because it is considered a real "marker" of group membership and gi ves existence [21]. Therefore, justice can improve the performance of employees because of its ability to provide fair treatment related to membership in the organization. This means that if the government apparatus has good multicultural competence, it can increase interactional justice and ultimately affect performance [22]. Based on this explanation, it is obtained the hypothesis that is: H2: Multicultural competence has an indirect effect on the performance of apparatur through its ability to create interactional justice.

\section{METHOD}

\subsection{Research Design}

This study is a quantitative research conducted in cross section. Lampung Province was chosen as a research place because it is an immigrant area. The logical consequence of immigrant areas is that community members have a high degree of multicultural dynamics, such as local languages, customs, customs and different religions.

Determination of research sample using purposivesampling technique. Reference [23] explains that purposive sampling is a method of determining the sample with certain considerations. Sample of this study includes employees of government officials in three districts / cities, namely East Lampung, Central Lampung and Metro City. Data were collected by a survey questionnaire. The study collected 150 respondents. The data processed in this study were 143 because seven questionnaires were incomplete and excluded from the sample.

Analysis on the data used Structural Equation Model (SEM) operated under AMOS application program. Data quality was tested using confirmatory factor analysis. If the resulting probability is significant there is no difference between the sample covariance matrix and the estimated population covariance matrix; or if the regression weight indicates the critical ratio value $(C R)>2.0$ means these variables are significantly the dimensions of the latent 
variables established [24]. The final stage of structural equation model estimation is a full model analysis to see the suitability of the causality relationship built into the model. The relationship of model causality can be known based on the value of regression weight. If the critical ratio $(\mathrm{CR})> \pm$ 1.96 with significance level $<0.05$ then exogenous variables affect the endogenous variables, and if the value of $\mathrm{CR}< \pm 1.96$ with significance level $>0.05$ then exogenous variables have no effect on endogenous variables.

\subsection{Measurement instruments}

\subsubsection{Multicultural competence}

Multicultural competence is the ability to understand the identity and value of the various cultures that are embraced by it and how they affect their perceptions of others from different cultures. Culture is the pattern of beliefs, behaviors, and values maintained by groups of interacting people [25], [26]. Multicultural competence is measured using seven-item instruments, including: having knowledge of one's own culture as well as another's culture; able to decipher the existing cultural differences; sensitive to verbal and non-verbal symbols; able to interact and communicate with people who have cultural differences; and designing communication strategies and intercultural interactions. The Cronbach alpha of 0.821 (table 1) indicates high internal consistency. Satisfactory factor loading results of above 0.5 from a confirmatory factor analysis are found for the seven-items.

\subsubsection{Interactional justice}

Interactional justice is a perception of fairness in the interaction between an apparatus with his boss and with other apparatus. This variable was measured using a sixitem instrument developed by Moorman [27]. Broadly speaking these instruments include: (1) a respectable dimension that explains how the apparatus treats others respectfully; (2) the truthfulness dimension that explains how the apparatus makes decisions honestly and fairly; (c) the justification dimension that explains the decisionmaking procedure and how the decision results. The factor loading results of a confirmatory factor analysis that all items loaded above the 0.5 benchmark. A Cronbach alpha of 0.735 is obtained (table 1 ). This indicates satisfactory internal consistency for the items in the instrument.

\subsubsection{Apparatus performance.}

Performance is the result of work in quality and quantity achieved by an employee in performing its functions in accordance with the responsibilities given to it. Instruments of apparatus performance in this study as developed by Linda Coopmans et al [28]. Apparatus performance consisted of task performance, contextual performance, and counterproductive work behavior. The factor loading results of a confirmatory factor analysis that all items loaded above the 0.5 benchmark. A Cronbach alpha of 0.766 is obtained (Table 1). This indicates satisfactory internal consistency for the items in the instrument.

\section{RESULT}

\subsection{Descriptive statistic}

A summary of descriptive statistics of each research variable is presented in Table 1 . Table 1 shows that the multicultural competence of government apparatus has a range of actual values between 11 to 34 , an average value of 23.39 and a standard deviation of 4.475 . The actual average value is above the averaged theoretical value (23.39 $>21$ ). Interactional justice variables have a range of actual values between 11 to 29 , an average value of 21.20 and a standard deviation of 3.414 . While the performance of government apparatus has a range of actual values between 9 to 25 , the average value of 17.53 and the standard deviation of 2825 . Thus, the actual average value is greater than the theoretical average value $(17.53>15)$. These results indicate that all variables, namely multicultural competence, interactional justice and performance of government apparatus in Lampung Province are at a good level.

Table 1 Descriptive statistics and cronbach alphas

\begin{tabular}{|ccccccccc|}
\hline & \multirow{2}{*}{ Mean } & \multirow{2}{*}{ Std. Deviation } & \multicolumn{3}{c}{ Actual range } & \multicolumn{2}{c|}{ Theoretical range } & \multirow{2}{*}{$\begin{array}{c}\text { Cronbach } \\
\text { alpha }\end{array}$} \\
\cline { 4 - 7 } & & & Min & Max & Min & Max & \\
\hline Mult.Competence & 23.39 & 4.475 & 11 & 34 & 7 & 35 & 0.821 \\
Int.Justice & 21.20 & 3.414 & 11 & 29 & 6 & 30 & 0.735 \\
App.Performace & 17.53 & 2.825 & 9 & 25 & 5 & 25 & 0.766 \\
\hline
\end{tabular}

\subsection{Model fit assessment}

Reference [24] shows the recommended value for the fit structural equation model test is $\mathrm{p} \geq 0,05 ; \mathrm{CMIN} / \mathrm{DF} \leq 2,00$;
$\mathrm{GFI} \geq 0.90 ; \mathrm{AGFI} \geq 0.90$; and $\mathrm{RMSEA} \leq 0.08$. The results of this test result Chi-Square value 235.102 with probability $p$ $=0,000$, GFI $=0.834$ and $\mathrm{AGFI}=0.785$. Based on this criterion, then the model is accepted at the marginal level. While the value of CMIN / DF $=1.451$, RMSEA $=0.066$ has been recommended accordingly so that the proposed model is accepted at the fit level. Reference [29] shows that 
Chi-square value is very sensitive to sample size, so that there is a tendency of Chi-square value to be always significant. Therefore, it is advisable to ignore it and see other goodness fit. SEM analysis there is no single statistical test tool to measure or test hypotheses about the model [24]. The statement provides enough evidence that there are various types of fit index that can be used to measure the degree of conformity that a model is acceptable.

Table 2 Value of CMIN

\begin{tabular}{|cccccc|}
\hline Model & NPAR & CMIN & DF & P & CMIN/DF \\
\hline Default model & 48 & 235,102 & 162 &, 000 & 1,451 \\
Saturated model & 210 &, 000 & 0 & & \\
Independence model & 20 & 880,016 & 190 &, 000 & 4,632 \\
\hline
\end{tabular}

Table 3 Value of RMR, GFI and GFI

\begin{tabular}{|lrrrr|}
\hline \multicolumn{1}{|c}{ Model } & \multicolumn{1}{c}{ RMR } & \multicolumn{1}{c}{ GFI } & \multicolumn{1}{c|}{ AGFI } & PGFI \\
\hline Default model &, 066 &, 834 &, 785 &, 643 \\
Saturated model &, 000 & 1,000 & & \\
Independence model &, 203 &, 416 &, 354 &, 376 \\
\hline
\end{tabular}

Table 4 Value of RMSEA

\begin{tabular}{|lcccc|}
\hline \multicolumn{1}{|c}{ Model } & RMSEA & LO 90 & HI 90 & PCLOSE \\
\hline Default model &, 066 &, 046 &, 083 &, 089 \\
Independence model &, 186 &, 174 &, 198 &, 000 \\
\hline
\end{tabular}

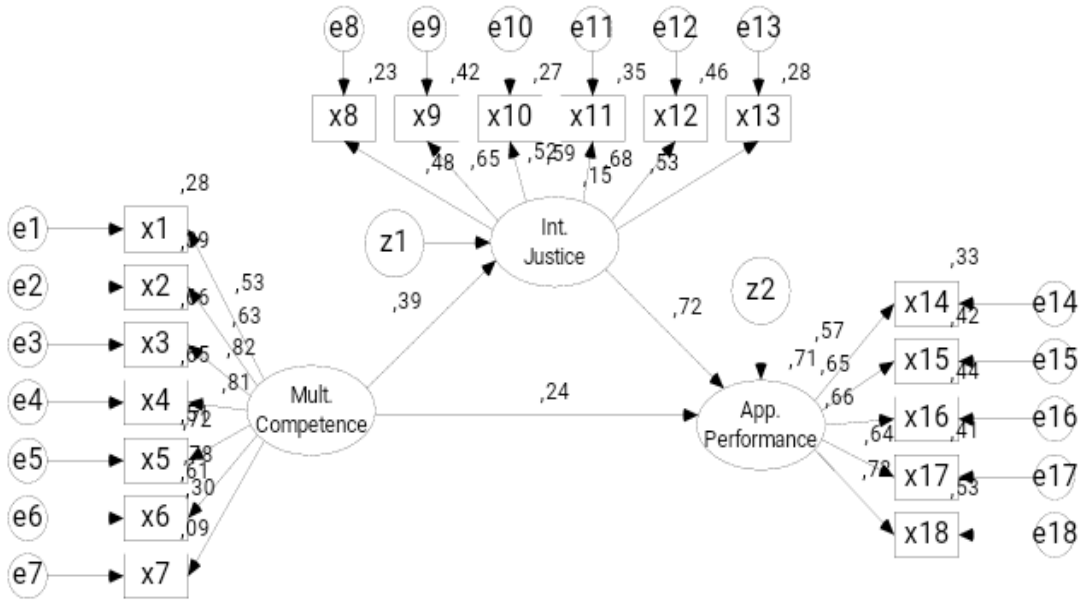

Figure 2 Full structural equation model

\subsection{Hypothesis testing and discussion}

Figure 2 is a full structural equation model construct after confirmatory factor analysis and testing of goodness of fit

indices full structural model. Testing result of the research hypothesis using AMOS program in the form of output regression weights is shown in Table 5 . Whilst, the output relationship between exogenous variables to endogenous variables can be seen from estimate standardized regression weights shown Table 6 .

Table 5 Regression weights

\begin{tabular}{|ccccccc|}
\hline & & & Estimate & S.E. & C.R. & P \\
\hline Int._Justice & $<---$ & Mult._Competence &, 522 &, 205 & 2,551 &, 011 \\
App._Performance & $<---$ & Int._Justice &, 918 &, 251 & 3,656 & $* * *$ \\
App._Performance & $<---$ & Mult._Competence &, 416 &, 192 & 2,163 &, 031 \\
\hline
\end{tabular}


Table 6 Standardized regression weights

\begin{tabular}{|cccc|}
\hline & & & Estimate \\
\hline Int._Justice & $<---$ & Mult._Competence &, 385 \\
App._Performance & $<---$ & Int._Justice &, 720 \\
App._Performance & $<---$ & Mult._Competence &, 241 \\
\hline
\end{tabular}

\subsubsection{Multicultural competence and performance of government apparatus.}

The result of parameter estimation test between multicultural competence and performance of government apparatus shows the influence of 0,241 and critical ratio value $(\mathrm{CR}) 2,163$ with $\mathrm{p}$-value $0,031(\mathrm{p}<0,05)$. The results of this study indicate that multicultural competence has a significant direct effect on performance of government apparatus. Culture is the pattern of beliefs, behaviors, and values maintained by groups of interacting people [26]. Someone who has high multicultural competence tends to be able to describe the existing cultural differences, sensitive to verbal and non-verbal symbols, able to interact and communicate with people who have different cultures. This form of understanding and attitude will create a better working relationship and motivate employees to work optimally. This implies that the achievement of performance can be done through the improvement of multicultural competence for the government apparatus.

Performance is a combination of ability and traits, effort and support as measured by the work achieved by a person [30], [31]. Many performance studies have been conducted and each state that performance is positively correlated with several important variables, namely personality [32], trust in supervisors [33], locus of control, employee empowerment [34], organizational citizenship behavior [35]. Reference [36] explains that one of the factors that must be considered in order to produce a high level of performance is to pay attention to issues considered important by employees. Furthermore, the multicultural competence within an organization reflects the ability of employees to engage in action and create situations that maximize individual performance. Thus, the results of this study are not surprising because multicultural competence was created to improve the performance of government apparatus. In management control theory, well-allocated multicultural competence can produce harmonious working relationships. This condition will encourage new innovations and be able to provide added value for the organization. This added value shows the level of quantity and the quality of achievement of organizational goals so as to reflect the performance of employees.

Finally, this study concluded that multicultural competence becomes a characteristic that realizes the individual or someone achieves high performance in his work. Characteristics that arise in the form of understanding, attitude and individual skills to create an apparatus that has a high spirit of dedication in serving people who always act efficiently, rationally, transparently and accountably. These findings support the opinions of some previous researchers such as [14], [15], [16] and [17]. They argue that the competence and degree of awareness of cultural differences is an important determinant in improving employee performance. Reference [37] shows that performance management practices and employee attitudes are crucial for achievement of managed performance.

\subsubsection{Multicultural competence, interactional justice and performance of government apparatus.}

The result of estimation test of indirect influence between multicultural competence, interactional justice and performance of government apparatus is shown in table 6 and Table 7.

Table 7 Standardized direct effects, inderct effect and total effects

\begin{tabular}{|ccccc|}
\hline $\begin{array}{c}\text { Exogenous } \\
\text { Variable }\end{array}$ & $\begin{array}{c}\text { Endogenous } \\
\text { Variable }\end{array}$ & $\begin{array}{c}\text { Direct effect } \\
\text { Indirect } \\
\text { effect }\end{array}$ & $\begin{array}{c}\text { Total } \\
\text { effect }\end{array}$ \\
\hline Mult._Competence & App._Performance Int._Justice & 0,241 & 0,277 & 0,518 \\
Mult._Competence & App._Performance & 0,385 & - & 0,385 \\
Int._Justice & & 0,720 & - & 0,720 \\
\hline
\end{tabular}

Based on the table 5 and table 7 shows that the influence of multicultural competence on interactional justice is 0.385 with the critical ratio value $(\mathrm{CR})=2.55$ and $p$-value 0.011 . This study indicates that multicultural competence has an effect on interactional justice. Reference [6] explains that someone who has high multicultural competence is characterized by an understanding to empathize or be able to feel the feelings of others. They are able to understand and accept others who differ, think, interact, behave and in different ways of making decisions. This multicultural competence will give rise to high attitude and individual skill. Attitudes reflect the evaluative statements about our culture with other people's cultures, and respond positively to the cultural differences. Attitudes are always related to emotional components, cognitive components (perceptions, opinions, beliefs) and behaviors. This means that the apparatus will do the job well if the three components are in accordance with them personality. While skills reflect the ability to actualize cultural competence in the form of real behavior [38]. These results provide empirical evidence of the influence of multicultural competence on interactional justice.

The effect of interactional justice on apparatus performance is 0.720 (table $5 \&$ table 7 ) with $\mathrm{CR}=3,656$ and $\mathrm{p}$-value 
[2] D. Matsumoto dan L. Juang, "Culture and psychology," third Edition, USA:

Wadsworth/Thomson, 2004.

[3] R. Linton and J Melville. Herskovits, Memorandum for the Study of Acculturation. American:

Anthropologist, 2001

[4] D. Maheswaran and S. Shavitt, "Issues and New Directions in Global Consumer Psychology," J.

Consum. Psychol., vol. 9, no. 2, pp. 59-66, 2000.

[5] J. T. Armstrong, Regional Economics and Policy, Third Edition. Oxford: Blackwell Publishing, 2000.

[6] G. McAllister and J. J. Irvine, "Cross Cultural Competency and Multicultural Teacher Education," Rev. Educ. Res., vol. 70, no. 1, p. 3, 2000.

[7] J. Moule, "Cultural Competence; A Primer for Educators," second edition, Wadsworth: Cengage Learning, 2012.

[8] S. Sinha, A. Kr. Singh, N. Gupta, and R. Dutt, "Impact of Work Culture on Motivation and Performance of Employees in Private Sector Companies," Journal of Public School of Business, New Delhi: University of Delhi, 1996.

[9] M. Harper, M. Hernandez, T. Nesman, D. Mowery, J. Worthington, \& M. Isaacs, "Organizational cultural competence: A review of assessment protocols," Making children's mental health services successful series, FMHI pub. no. 240-2, 2006.

[10] L. F. Ramírez and J. E. Rubio, "Culture, Government and Development in South Korea," Asian Cult. Hist., vol. 2, no. 1, 2010.

[11] S. N. Lenda, "Influence culturizes bureaucracy to apparatus performance at Regency Region secretariat Bolaang Mongondow North," Jurnal Acta Diurna, Vol.2, No. 4, 2013.

[12] D. Riswanto, Mappiare and Irtadji, Journal of Multicultural Studies in Guidance and Counseling, Vol. 1. No.2, p.215-226, 2017.

[13] T. K. Yeremias, Indikator Kinerja Pemerintah Daerah, Yogyakarta: UGM, 2005.

[14] J. Hladik, "Design and Development of a Multicultural Competence Scale in Helping-Profession Students," Asian Soc. Sci., vol. 10, no. 9, 2014.

[15] A. A. Albdour and I. I. Altarawneh, "Employee Engagement and Organizational Commitment : Evidence from Jordan," International

[1] S. P. Robbins and T. A. Judge, "Perilaku Organisasi," (translator by Benyamin Molan) Ed. kesepuluh, Jakarta: PT Mancana Jaya Cemerlang, 2006. 
citizenship?,” J. Appl. Psychol., vol. 76, no. 6, pp. 845$855,1991$.

[28] L. Koopmans, C. Bernaards, V. Hildebrandt, S. van Buuren, A. J. van der Beek, and H. C. W. de Vet, "Development of an individual work performance questionnaire,” Int. J. Product. Perform. Manag., vol. 62, no. 1, pp. 6-28, 2012.

[29] I. Ghozali, "Model Persamaan Struktural; Kosep dan Aplikasi dengan Program Amos 16.0," Universitas Diponegoro: Semarang, 2015.

[30] L. W. Porter, G. A. Bigley, and R. M. Steers, "Motivation and work behavior," New York: Mc:Graw, 1983.

relationship between budgetary participation and performance," Adv. Account., vol. 19, pp. 139-160, 2002.

[19] C. M. Lau and A. Moser, "Behavioral Effects of Nonfinancial Performance Measures: The Role of Procedural Fairness," Behav. Res. Account., vol. 20, no. 2, pp. 55-71, 2008.

[20] J. Rawls, “A Theory of Justice,” Cambridge. MA: Harvad Universisty Press, 1971.

[21] E. A. Lind and T. R. Tyler, "Introduction," The Social Psychology of Procedural Justice. Springer US, pp. 1-6, 1988.

[22] J. Peng et al., "The Impact of Psychological Capital on Job Burnout of Chinese Nurses: The Mediator Role of Organizational Commitment," PLoS One, vol. 8, no. 12, p. e84193, 2013.

[23] N. Sudjana, "Metode statistika," Bandung: Tarsito, vol. 168, 2005.

[24] A. Ferdinand, "Structural equation modeling dalam penelitian manajemen," Semarang Badan Penerbit Univ. Diponegoro, 2010.

[25] F. Trompenaars and C. Hampden-Turner, Riding the waves of culture: Understanding diversity in global business. London: Nicholas Brealey International, 2012.

[26] M, Bennett, Intercultural competence for global leadership. Available: https://5a07ac3d-a-62cb3a1a-ssites. googlegroups.com/site/ sgsprofessional outreach/BennettIntercultural Communication.pdf, 2016

[27] R. H. Moorman, "Relationship between organizational justice and organizational citizenship behaviors: Do fairness perceptions influence employee
[31] U.-C. Klehe and N. Anderson, "Working hard and working smart: Motivation and ability during typical and maximum performance.," J. Appl. Psychol., vol. 92, no. 4, pp. 978-992, 2007.

[32] M. R. Barrick and M. K. Mount, "The big five personality dimensions and job performance: a metaanalysis," Pers. Psychol., vol. 44, no. 1, pp. 1-26, 1991.

[33] Z. X. Chen, A. S. Tsui, and J.-L. Farh, "Loyalty to supervisor vs. organizational commitment:

Relationships to employee performance in China," J. Occup. Organ. Psychol., vol. 75, no. 3, pp. 339-356, 2002.

[34] K. S. Rahman, “Analisis Pengaruh Locus of Control dan Kepercayaan Terhadap Pemberdayaan Karyawan dalam Peningkatan Kinerja Karyawan," Semarang: Universitas Diponegoro, 2009.

[35] W. H. Bommer, E. C. Dierdorff, and R. S. Rubin, "Does Prevalence Mitigate Relevance? The Moderating Effect of Group-Level OCB on Employee Performance," Acad. Manag. J., vol. 50, no. 6, pp. 1481-1494, 2007.

[36] A. G. Hopwood, “An Empirical Study of the Role of Accounting Data in Performance Evaluation," J. Account. Res., vol. 10, p. 156, 1972.

[37] J. Kagaari, J. C. Munene, and J. Mpeera Ntayi, "Performance management practices, employee attitudes and managed performance," Int. J. Educ. Manag., vol. 24, no. 6, pp. 507-530, 2010.

[38] J. L. Gibson, J. M. Ivancevich, J. H. Donnelly, "Organizational and Process Structure Behavior," (translitor by Nunuk Andriani), Jakarta: Bina Putra, 1996. 
[39] K. W. Thomas and B. A. Velthouse, "Cognitive Elements of Empowerment: An 'Interpretive' Model of Intrinsic Task Motivation,” Acad. Manag. Rev., vol. 15, no. 4, pp. 666-681, 1990.

[40] G. Abekah-Nkrumah and R. Ayimbillah Atinga, "Exploring the link between organisational justice and job satisfaction and performance in Ghanaian hospitals," Int. J. Work. Heal. Manag., vol. 6, no. 3, pp. 189-204, 2013.

[41] R. Folger and M. A. Konovsky, "Effects of Procedural and Distributive Justice on Reactions to Pay Raise Decisions," Acad. Manag. J., vol. 32, no. 1, pp. 115-130, 1989. 